\title{
POTENTIAL USE OF ALLUVIAL GROUNDWATER FOR IRRIGATION IN ARID ZONES - MHAMID OASIS (S MOROCCO)
}

\author{
PRZYDATNOŚĆ WÓD ALUWIALNYCH DO NAWADNIANIA \\ W OBSZARACH SUCHYCH - OAZA MHAMID (PLD MAROKO)
}

\begin{abstract}
In arid zones, the availability of fresh water is usually very limited because of high salinity, which greatly limits their use for irrigation purposes. High mineralization of water used for irrigation leads to increased soil salinity. The aim of the study was to examine the potential use of alluvial groundwater for irrigation in arid zones. The works were conducted in the Middle Draa Valley in southern Morocco (the Mhamid Oasis) in October 2015. Water samples of alluvial groundwater were collected for laboratory analysis from 42 wells located in the oasis. In order to determine the possibility to use the water for irrigation purposes, the Sodium Adsorption Ratio $(S A R)$, sodium percentage $(\% N a)$, permeability index $(P I)$, Kelly's ratio $(K R)$, magnesium hazards $(M H)$ and electrical conductivity $(E C)$ were assessed. $E C$ values, exceeding $3000 \mu \mathrm{S} \cdot \mathrm{cm}^{-1}$ in all the samples, classify the water as unsuitable for irrigation. $M H$ and the $K R$ indexes show that $30 \%$ of water samples represent levels making them unsuitable for irrigation. SAR confirms the very high degree of susceptibility of the analyzed waters to salinity hazard. The PI index of these waters is moderate, however in terms of sodium content they can be deemed suitable for irrigation purposes. It has been found that even within a small area of the oasis, a very large differentiation in the alluvial groundwater suitability for irrigation purposes occurs.
\end{abstract}

Keywords: groundwater salinity, alluvial aquifer, irrigation, arid zones

\section{Introduction}

Fresh water, coming from surface- and groundwaters, is crucial for human functioning. Water resources, their availability and quality are highly diversified, depending on a climate zone. In the arid zone, fresh water availability is usually significantly limited. Surface water as well as shallow groundwaters in the area are characterised by high salinity [1-4].

Water salinity is understood as content of dissolved mineral salt. In hot, arid areas, water enrichment in mineral salts is related to small amount of rainfall and intense

\footnotetext{
${ }^{1}$ Department of Geomorphology, Faculty of Geography and Regional Studies, University of Warsaw, ul. Krakowskie Przedmieście 30, 00-927 Warszawa, Poland, email: dluzewski@uw.edu.pl

${ }^{2}$ Department of Environmental Protection and Modelling, Faculty of Mathematics and Natural Sciences, The Jan Kochanowski University in Kielce, ul. Świętokrzyska 15, 25-406 Kielce, Poland, email: rafalka@ujk.edu.pl

${ }^{3}$ Department of Hydrometry, Faculty of Geography and Geological Sciences, Adam Mickiewicz University in Poznań, ul. B. Krygowskiego 10, 61-680 Poznań, Poland, email: szana@amu.edu.pl

* Corresponding author: rafalka@ujk.edu.pl
} 
evapotranspiration, what results in gathering and precipitation of salts, which can be dissolved again by surface waters. In ground waters, salt is mainly washed out from stone formations, because of what salts of sodium, chlorine, magnesium, calcium, potassium as well as sulphates and bicarbonates permeate to water solutions. The parameter characteristic for the content of salts dissolved in water is electric conductivity $(E C)$. The higher its value is, the higher is the salinity. It is assumed that for water for irrigation purposes the EC should range from 600 to $1700 \mu \mathrm{S} \cdot \mathrm{cm}^{-1}$ [5]. However, values are higher in many areas in the hot, arid zone, what makes their usage for irrigation purposes significantly limited [6-9]. Nonetheless, as there are no other sources of water, they are used for irrigation, what leads to increased soil salinity. The problem occurs in more than hundred countries, encompassing $0.95 \mathrm{Gha}$, what constitutes approximately $7.3 \%$ of the land surfaces $[8,10]$. The total surface degraded because of irrigation with salinated water is estimated at $80 \%$ in Turkmenistan [11] and at approximately $30 \%$ in Egypt $[12,13]$, Iran [4] and Pakistan [14]. The problem has also been observed in India [6], China [15] and in the USA [11], where the area of degraded soil is estimated at $20 \%$. Water salination has also been researched in Morocco [1, 16, 17]. The processes influencing the chemistry and creating high salinity of shallow groundwaters have been analysed in these papers.

Using excessively salinated water for irrigation is one of the most common reasons of soil degradation, leading to desertification that results in loss of soil fertility, has adverse effects for its structure and leads to its densification and crust. Accumulation of salts (in particular - sodium) is one of the major physiological threats for ecosystems. Salt disrupts plants development by hindering intake of nutrients and lowering the quality of water a plant uses. It also affects the metabolism of soil-dwelling organisms, leading to serious lowering of soil fertility. High salinity of soil results in plants dying because of rising osmotic pressure and toxicity of salts. Moreover, excess of sodium destroys the soil structure, what results in its loss of ability to support plant growth and animal life, because of lack of oxygen. In consequence, salinity increases soil-sealing, making it unsuitable for cultivation. Additional factor in the high evapotranspiration areas, what increases water salinity and, in consequence, soil salinity is inappropriate field irrigation practice consisting in spreading water by open channels, what also contributes to high water losses.

The area in which surface waters are currently the major source of water for irrigation is South Morocco. The irrigation of the oases located in the valley is conducted with the use of water collected in the reservoir Mansour Ed Dahbi. Water from the reservoir has been released several times during the growing season to enable irrigation of fields. A variable supply of water to the reservoir, gradual reduction of its volume resulting from a large material supply transported during extreme river floods and increasing households' water consumption in the nearby cities, resulted in the need to search for the alternative sources of water for irrigation purposes.

The aim of the study was to assess the usability of alluvial waters for irrigation in hot arid zone. As such areas, located even hundreds kilometres from water reservoirs, are often omitted in irrigation plans, the importance of alluvial waters increases. Their usage depends on their quality as well as on the economic status of the citizens.

\section{Study area}

The research has been conducted in the Draa river valley in South Morocco (Fig. 1). The area is located in the hot arid zone. It is characterised by very low rainfall $(50 \mathrm{~mm})$ and 
high evapotranspiration reaching $3500 \mathrm{~mm}$. Average temperature in summer is $32^{\circ} \mathrm{C}$ and in winter $-13^{\circ} \mathrm{C}$. Morocco is one of the areas where access to fresh water is limited and agriculture is dependent on periodic water supplies. The inhabitants of oasis located in the Draa river valley use for irrigation purposes mainly the waters gathered in the Mansour Ed Dahbi reservoir, built in 1972, discharged few times during the vegetation season, what makes it possible to irrigate the fields.

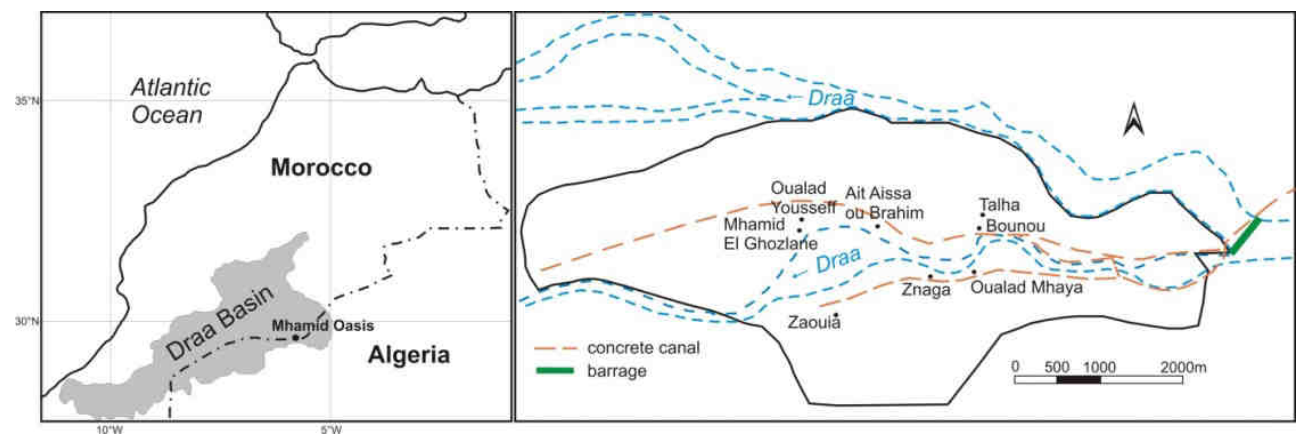

Fig. 1. Study area location and the irrigation channel system

Considering irregular water supply to the reservoir, its gradual volume reduction, resulting from a great supply of supplied material transported during extreme rising in the supplying rivers and extensive water intake for the needs of the inhabitants of the cities nearby, there a great need occurred to search for alternative water sources. The area most affected is the Mhamid Oasis, with its 10,000 inhabitants, the last of six oases in the Middle Draa valley, that is why the study has been conducted there. The water flows through the Draa riverbed and in its alluvia and is banked on a dam above the Mhamid. By the system of valves, it is directed to the irrigation system, comprising of main channels of reinforced concrete, located along river valley. Then, from the main channels, water is directed to secondary channels carrying water to the fields. Using the system of open channels results in significant loses of water because of intense evapotranspiration. Moreover, the channels are susceptible to be strewn by blown out material. The excess of water enters the riverbed and infiltrates the alluvia. The alluvia are mainly build of gravel and stones, most of them of a diameter between 5 and $10 \mathrm{~cm}$, maximum diameter - approximately $100 \mathrm{~cm}$. Because of irregular supply of the current irrigation system by water discharges from the Mansour Ed Dahbi dam, during which the water flows for 7 days, 4-5 times a year, also supplying wells from the Oasis are used for irrigation purposes. Their water intake, with the use of motor or electric pumps, is expensive, though, so only a little more than $10 \%$ fields in the oasis is irrigated in this way. However, during last years lowering of groundwater level has been observed. In 1967, the depth to the groundwater table amounted from 2 to 8 meters, in 2005 , from 3 to 12 meters $[18,19]$, and in 2015, it ranged from 6.5 to 17 m p.p.t.

\section{Methods}

Alluvial waters for laboratory analyses were sampled in October 2015 from 42 wells in the Mhamid Oasis. In the field, the electric conductivity was measured with a conductivity meter CC-401 by Elmetron, with automatic compensation to a reference temperature of 
$25^{\circ} \mathrm{C}$ and accuracy $\pm 1 \%$ and $\pm 1^{\circ} \mathrm{C}$ respectively. The $\mathrm{pH}$ was measured with a $\mathrm{pH}$ meter $\mathrm{CP}-411$ by Elmetron, with an accuracy of $0.01 \mathrm{pH}$ units. The water samples for chemical analysis put into polyethylene bottles and transported to the laboratory in cold storage. Before the analyses, samples were filtered with the glass fibre filter of a diameter of $25 \mathrm{~mm}$ and pore diameter of $0.45 \mu \mathrm{m}$ (Whatman glass microfiber). Cations $\left(\mathrm{Ca}^{2+}, \mathrm{Mg}^{2+}, \mathrm{K}^{+}, \mathrm{Na}^{+}\right)$ and anion $\mathrm{Cl}^{-}$were determined by ion chromatography on an ICS3000 DIONEX equipment, with an analytical column IonPac CS16 $3.250 \mathrm{~mm}$ (cations) and IonPac AS18 $2.250 \mathrm{~mm}$ (anions). Bicarbonates $\left(\mathrm{HCO}_{3}{ }^{-}\right)$were marked by titration. The limits of quantification for the given parameters amounted: for $\mathrm{Ca}^{2+}-0.4 \mathrm{mg} \cdot \mathrm{dm}^{-3}$, for $\mathrm{Mg}^{2+}$, $\mathrm{Na}^{+}-0.2 \mathrm{mg} \cdot \mathrm{dm}^{-3}$, for $\mathrm{K}^{+}-0.1 \mathrm{mg} \cdot \mathrm{dm}^{-3}$, for $\mathrm{Cl}^{-}-0.1 \mathrm{mg} \cdot \mathrm{dm}^{-3}$.

To assess the usability of waters for irrigation, the following tools were used:

- $\quad$ Sodium adsorption ratio $(S A R)$, calculated with the use of the formula (1) proposed by Richards [20]. The $\mathrm{Na}^{+}, \mathrm{Ca}^{2+}, \mathrm{Mg}^{2+}$ ions concentration is expressed as [meq $\mathrm{dm}^{-3}$ ]

$$
S A R=\frac{N a^{+}}{\sqrt{\frac{\left(C a^{2+}+M g^{2+}\right)}{2}}}
$$

- $\quad$ Sodium total percentage $(\% \mathrm{Na})$, calculated with the use of the formula (2). The $\mathrm{Na}^{+}$, $\mathrm{Ca}^{2+}, \mathrm{Mg}^{2+}$ and $\mathrm{K}^{+}$ions concentration is expressed as $\left[\mathrm{meq} \cdot \mathrm{dm}^{-3}\right.$ ]

$$
(\% \mathrm{Na})=\frac{\left(\mathrm{Na}^{+}+\mathrm{K}^{+}\right) \cdot 100}{\left(\mathrm{Ca}^{2+}+\mathrm{Mg}^{2+}+\mathrm{Na} \mathrm{a}^{+}+\mathrm{K}^{+}\right)}
$$

- Permeability index $(P I)$ calculated with the use of the formula (3) according to Ragunath [21]. The $\mathrm{Na}^{+}, \mathrm{Ca}^{2+}, \mathrm{Mg}^{2+}$ ins and $\mathrm{HCO}_{3}^{-}$concentration is expressed as $\left[\mathrm{meq} \cdot \mathrm{dm}^{-3}\right]$

$$
P I=\frac{\left(\mathrm{Na}^{+}+\sqrt{\mathrm{HCO}_{3}^{-}}\right)}{\left(\mathrm{Ca}^{2+}+\mathrm{Mg}^{2+}+\mathrm{Na}^{+}\right)} \cdot 100
$$

- Kelly's ratio $(K R)$, calculated with the use of the formula (4) proposed by Kelly [22]. The $\mathrm{Na}^{+}, \mathrm{Ca}^{2+}, \mathrm{Mg}^{2+}$ ions concentration is expressed as $\left[\mathrm{meq} \cdot \mathrm{dm}^{-3}\right.$ ]

$$
K R=\frac{N a^{+}}{\left(C a^{2+}+M g^{2+}\right)}
$$

- $\quad$ Magnesium hazard indicator $(M H)$, calculated according to Szabolcs and Darab [9] (5). The $\mathrm{Ca}^{2+}, \mathrm{Mg}^{2+}$ ions concentration is expressed as $\left[\mathrm{meq} \cdot \mathrm{dm}^{-3}\right.$ ]

$$
M H=\frac{M g^{2+}}{\left(C a^{2+}+M g^{2+}\right)} \cdot 100
$$

\section{Results}

Measured $\mathrm{pH}$ values ranging from 6.8 to 7.9 indicate that the waters are neutral to slightly alkaline. Electric conductivity of the researched waters ranged from 3,800 to $13,766 \mu \mathrm{S} \cdot \mathrm{cm}^{-1}$, what indicates that the waters are salty and their salinity increases 3.5 times from the east to the west of the oasis. The increase of concentration with the water flow direction is also characteristic for $\mathrm{Na}^{+}, \mathrm{Ca}^{2+}$ and $\mathrm{Mg}^{2+}$ ions. Values of $\mathrm{K}^{+}$and $\mathrm{HCO}_{3}{ }^{-}$ though, are shaped independently. Statistical description of the physicochemical parameters used for calculation is presented in Table 1.

Values of the indexes: $S A R,(\% N a), P I, K R$ and $M H$ for the given wells are presented in Table 2. 
Descriptive statistic of the physicochemical variables of groundwater samples $(n=42)$

\begin{tabular}{|c|c|c|c|c|c|}
\hline Parameter & Units & Min & Max & Mean & SD \\
\hline Water temperature & {$\left[{ }^{\circ} \mathrm{C}\right]$} & 20.2 & 26.3 & 24.2 & 1.2 \\
\hline$E C$ & {$\left[\mu \mathrm{S} \cdot \mathrm{cm}^{-1}\right]$} & 3,800 & 13,766 & 7,988 & 2.7 \\
\hline $\mathrm{pH}$ & $-\log \left[\mathrm{H}^{+}\right]$ & 6.8 & 7.9 & 7.3 & 0.3 \\
\hline $\mathrm{Cl}^{-}$ & {$\left[\mathrm{mg} \cdot \mathrm{dm}^{-3}\right]$} & 733 & 3312 & 1739 & 727 \\
\hline $\mathrm{Na}^{+}$ & {$\left[\mathrm{mg} \cdot \mathrm{dm}^{-3}\right]$} & 459 & 2438 & 1182 & 500 \\
\hline $\mathrm{Ca}^{2+}$ & {$\left[\mathrm{mg} \cdot \mathrm{dm}^{-3}\right]$} & 313 & 908 & 560 & 168 \\
\hline $\mathrm{Mg}^{2+}$ & {$\left[\mathrm{mg} \cdot \mathrm{dm}^{-3}\right]$} & 162 & 528 & 321 & 99 \\
\hline $\mathrm{K}^{+}$ & {$\left[\mathrm{mg} \cdot \mathrm{dm}^{-3}\right]$} & 4 & 55 & 14 & 10 \\
\hline $\mathrm{HCO}_{3}^{-}$ & {$\left[\mathrm{mg} \cdot \mathrm{dm}^{-3}\right]$} & 215 & 769 & 394 & 109 \\
\hline
\end{tabular}

$S D$ - standard deviation, $E C$ - electrical conductivity compensated at $25^{\circ} \mathrm{C}$

Table 2

Value of the indexes: $S A R,(\% N a), P I, K R$ and $M H$ for alluvial waters in the Mhamid Oasis $(n=42)$

\begin{tabular}{|c|c|c|c|c|c|}
\hline Well ID* & SAR & $(\% N a)$ & $P I$ & $K R$ & $M H$ \\
\hline Bea1 & 7.6 & 47.8 & 51.0 & 0.91 & 50.6 \\
\hline Bea2 & 7.5 & 48.2 & 51.5 & 0.92 & 48.9 \\
\hline Bea3 & 8.4 & 49.7 & 52.7 & 0.98 & 48.6 \\
\hline M04 & 7.8 & 44.1 & 46.8 & 0.79 & 44.9 \\
\hline M06 & 7.8 & 44.3 & 47.0 & 0.79 & 44.9 \\
\hline M09 & 10.6 & 49.5 & 51.6 & 0.98 & 46.9 \\
\hline Bea4 & 14.1 & 53.3 & 54.8 & 1.14 & 48.8 \\
\hline Bea5 & 9.1 & 45.4 & 47.4 & 0.83 & 48.8 \\
\hline Bea6 & 9.9 & 49.5 & 51.6 & 0.97 & 48.5 \\
\hline Bea7 & 14.4 & 53.5 & 55.1 & 1.15 & 50.4 \\
\hline Bea8 & 10.0 & 49.1 & 51.5 & 0.96 & 48.4 \\
\hline Bea9 & 10.9 & 50.2 & 52.3 & 1.00 & 49.1 \\
\hline Bea10 & 11.8 & 50.1 & 51.9 & 1.00 & 47.9 \\
\hline M16 & 15.2 & 53.7 & 55.1 & 1.16 & 50.3 \\
\hline M17 & 12.9 & 53.2 & 54.8 & 1.13 & 52.5 \\
\hline Bea11 & 12.7 & 51.1 & 52.8 & 1.04 & 50.3 \\
\hline M15 & 13.4 & 50.7 & 52.4 & 1.02 & 47.7 \\
\hline M14 & 16.1 & 55.1 & 56.8 & 1.22 & 50.1 \\
\hline Bea12 & 13.5 & 53.2 & 54.5 & 1.12 & 46.6 \\
\hline M01 & 7.5 & 41.2 & 43.9 & 0.70 & 45.3 \\
\hline Bea13 & 7.9 & 41.3 & 43.7 & 0.70 & 45.7 \\
\hline Bea14 & 8.0 & 42.7 & 45.1 & 0.74 & 50.7 \\
\hline Bea15 & 8.0 & 42.5 & 45.1 & 0.73 & 45.2 \\
\hline Bea17 & 9.0 & 47.9 & 50.7 & 0.91 & 46.7 \\
\hline Bea18 & 7.1 & 45.5 & 48.8 & 0.83 & 51.0 \\
\hline Bea19 & 5.2 & 41.0 & 44.8 & 0.69 & 45.9 \\
\hline Bea20 & 7.3 & 43.6 & 46.6 & 0.77 & 44.0 \\
\hline Bea21 & 8.4 & 45.5 & 48.1 & 0.83 & 47.4 \\
\hline Bea22 & 12.1 & 53.1 & 55.1 & 1.13 & 50.1 \\
\hline Bea25 & 7.5 & 44.1 & 46.9 & 0.79 & 48.4 \\
\hline Bea26 & 7.9 & 49.9 & 53.4 & 0.99 & 49.9 \\
\hline Bea37 & 8.0 & 50.3 & 53.6 & 1.01 & 50.0 \\
\hline Bea38 & 7.9 & 47.6 & 50.9 & 0.90 & 50.0 \\
\hline Bea39 & 10.7 & 48.8 & 50.7 & 0.95 & 48.8 \\
\hline Bea40 & 11.4 & 49.4 & 51.1 & 0.96 & 48.7 \\
\hline Bea41 & 9.2 & 45.3 & 47.4 & 0.82 & 48.3 \\
\hline CampIbra & 6.4 & 43.5 & 46.5 & 0.77 & 49.5 \\
\hline
\end{tabular}




\begin{tabular}{|c|c|c|c|c|c|}
\hline Well ID* & $\boldsymbol{S A R}$ & $(\boldsymbol{\%} \boldsymbol{N a})$ & $\boldsymbol{P I}$ & $\boldsymbol{K R}$ & $\boldsymbol{M H}$ \\
\hline Bea42 & 11.4 & 51.4 & 53.4 & 1.06 & 51.0 \\
\hline Bea43 & 8.1 & 49.8 & 52.8 & 0.99 & 49.6 \\
\hline Bea44 & 7.0 & 43.2 & 45.8 & 0.76 & 50.9 \\
\hline Bea46 & 7.1 & 44.8 & 47.7 & 0.80 & 48.2 \\
\hline Bea47 & 8.0 & 47.5 & 50.3 & 0.90 & 51.1 \\
\hline
\end{tabular}

*Well's ID in accordance with Figures 2-6

Percentage share of wells in particular classes of water usability for irrigation purposes is presented in the Table 3.

Table 3

Classification of alluvial waters in the Mhamid Oasis on the basis of their usability for irrigation purposes

\begin{tabular}{|c|c|c|c|}
\hline Parameters & Range & Class & Percentage of wells \\
\hline $\begin{array}{c}E C \\
{\left[\mu \mathrm{S}^{\circ} \mathrm{cm}^{-1}\right]}\end{array}$ & $\begin{array}{c}<250 \\
250-750 \\
750-2,000 \\
2,000-3,000 \\
>3,000\end{array}$ & $\begin{array}{l}\text { excellent } \\
\text { good } \\
\text { permissible } \\
\text { doubtful } \\
\text { unsuitable }\end{array}$ & 100 \\
\hline $\begin{array}{c}\mathrm{Cl}^{-} \\
{\left[\mathrm{meq} \mathrm{dm}^{-3}\right]}\end{array}$ & $\begin{array}{c}<5 \\
5-10 \\
>10\end{array}$ & $\begin{array}{c}\text { very good-good } \\
\text { good-hazardous } \\
\text { hazardous-very hazardous }\end{array}$ & 100 \\
\hline$S A R$ & $\begin{array}{r}<3 \\
3-9 \\
>9 \\
\end{array}$ & $\begin{array}{c}\text { safe } \\
\text { permissible } \\
\text { severe permeability problems }\end{array}$ & $\begin{array}{l}52 \\
48\end{array}$ \\
\hline$(\% \mathrm{Na})$ & $\begin{array}{c}<20 \\
20-40 \\
40-60 \\
60-80 \\
>80\end{array}$ & $\begin{array}{l}\text { excellent } \\
\text { good } \\
\text { permissible } \\
\text { doubtful } \\
\text { unsuitable }\end{array}$ & 100 \\
\hline$P I$ & $\begin{array}{c}<25 \\
25-75 \\
>75\end{array}$ & $\begin{array}{c}\text { safe } \\
\text { moderate } \\
\text { unsafe }\end{array}$ & 100 \\
\hline$K R$ & $\begin{array}{l}<1 \\
>1\end{array}$ & $\begin{array}{c}\text { suitable } \\
\text { unsuitable }\end{array}$ & $\begin{array}{l}69 \\
31\end{array}$ \\
\hline$M H$ & $\begin{array}{l}<50 \\
>50\end{array}$ & $\begin{array}{c}\text { suitable } \\
\text { unsuitable }\end{array}$ & $\begin{array}{l}67 \\
33\end{array}$ \\
\hline
\end{tabular}

\section{Discussion}

Using surface waters and groundwaters in the arid zone with high contents of dissolved salts for irrigation purposes is a serious problem for agriculture in the regions. As using the water for irrigation results in soil degradation and in limitations of plant growth, it is important to understand the qualities and usability of the water for irrigation purposes. Research like this is more and more frequently conducted in the developing countries, where the problem is the most significant and agriculture is the dominating economic sector. In this paper, the usability of alluvial waters from the area of South Morocco (the Mhamid Oasis), $10 \%$ of which are now used by the inhabitants of the Oasis for irrigation purposes, was assessed. The following parameters have been used: $\mathrm{pH}, E C$, sodium percentage, sodium adsorption ratio, Kelly's ratio, permeability index, and magnesium hazard. Alluvial waters are characterised by a $\mathrm{pH}$ ranging from 6.8 to 7.9. Considering that the best $\mathrm{pH}$ for the irrigation waters ranges from 6.5 to 7.0 , groundwaters of the Mhamid 
Oasis have a proper $\mathrm{pH}$ to be used for agricultural purposes. Nonetheless, considering the $E C$ values that, in all wells, exceed $3000 \mu \mathrm{S} \cdot \mathrm{cm}^{-1}$, according to Wilcox's [5] classification, the waters are not suitable for irrigation. Great amount of dissolved salts constitutes danger for crops and for soil itself, which undergoes salination and degradation, posing a serious risk for the development of agriculture [23]. The content of chlorides in alluvial waters that is higher than $10 \mathrm{meq} \cdot \mathrm{dm}^{-3}$ classifies the waters, according to the Doneen's [9] classification, as hazardous and very hazardous for irrigation. The high level of chlorides is toxic for plants, impedes their growth and lowers the quality and quantity of crops $[24,25]$. The ions of $\mathrm{Na}^{+}$have similar impact - their excess leads to disruptions in ionic balance in plants and limited intake of other ions that are crucial for proper plant growth [26]. Too high levels of $\mathrm{Na}^{+}$and $\mathrm{Cl}^{-}$ions result in such a significant change of chemical composition of soils solution that is disrupts also the intake of nutrients that are crucial for plants life, like magnesium, nitrogen and phosphorus [27-29]. The excess of sodium ions in soil solution is accompanied by calcium deficiency in plants, because as a result of ion exchange it may be removed from the environment of the roots. Excess of sodium ions results also in the potassium deficiency. Salinity caused by the sodium salts is the most damaging factor also for soil. Their increased value in the soil reduces their qualities, damages its granular structure, increases its dispersion state and ability to swell and, at the same time, reduces permeability and absorbability and leads to alkalisation [24, 26, 30]. The index informing about the usability of waters for irrigation in terms of content of sodium is sodium percentage (\% $\mathrm{Na}$ ) (Fig. 2). For the alluvial waters of the oasis, it ranges from 40 to $60 \%$ and classifies waters as permissible for irrigation purposes. The class indicates that they can still negatively affect the structure and permeability of the soil [31].

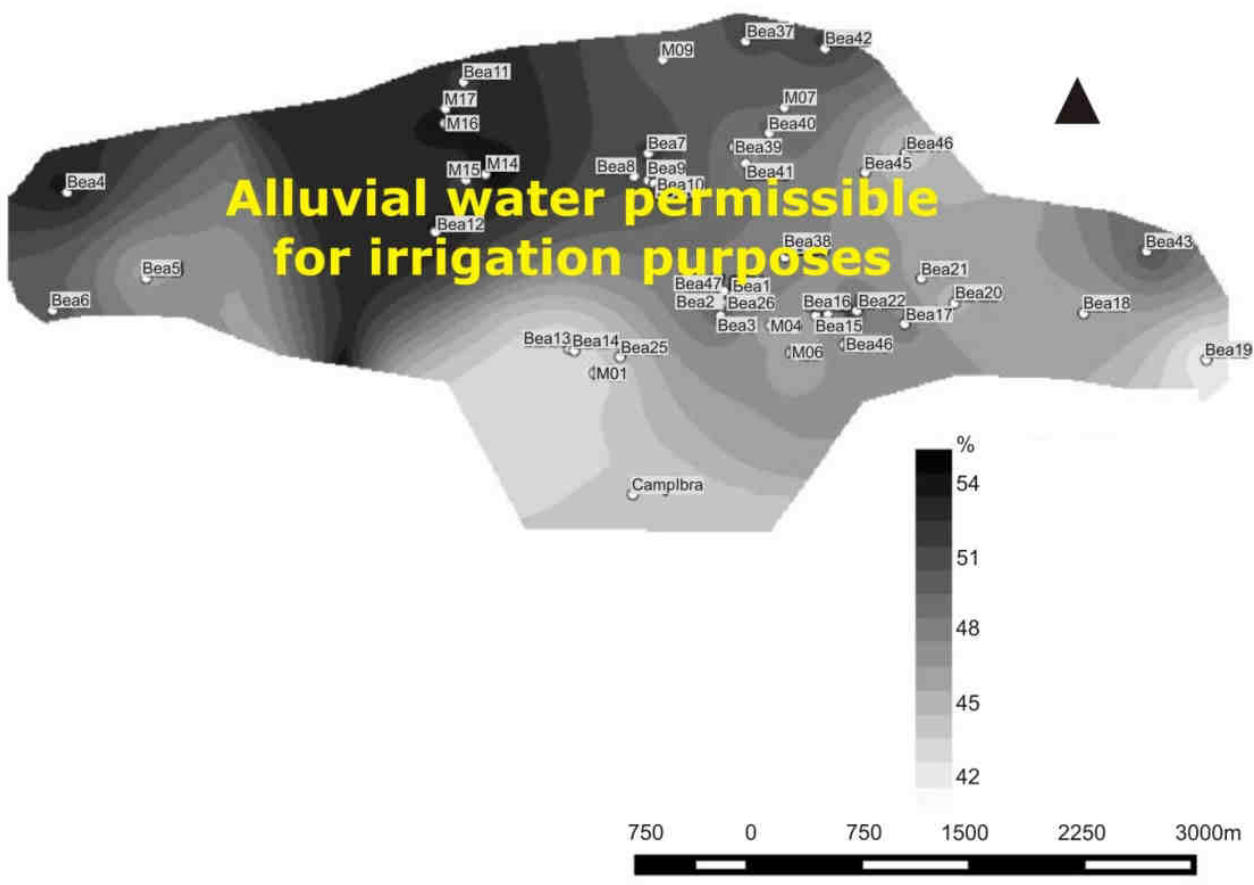

Fig. 2. Sodium percentage for alluvial water of Mhamid Oasis in October 2015 

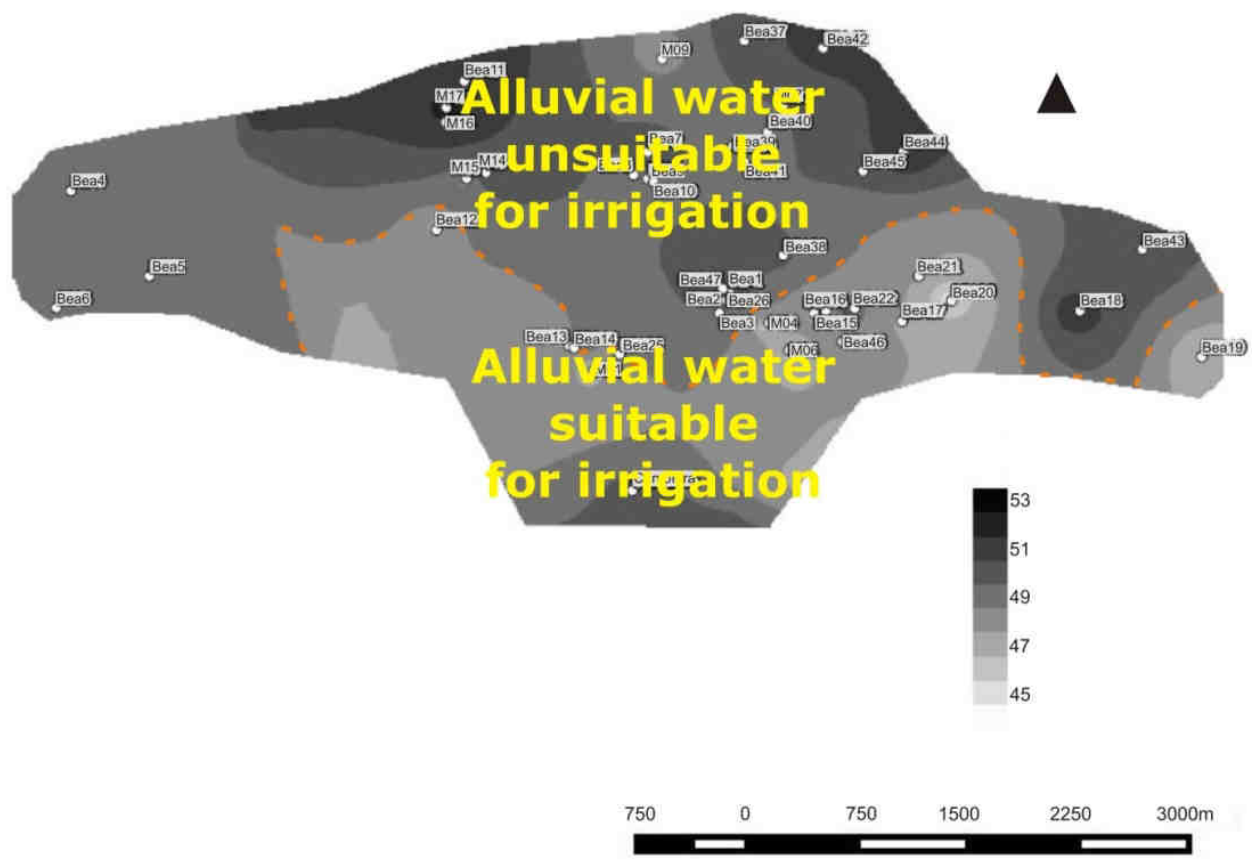

Fig. 3. Magnesium hazard for alluvial water of Mhamid Oasis in October 2015
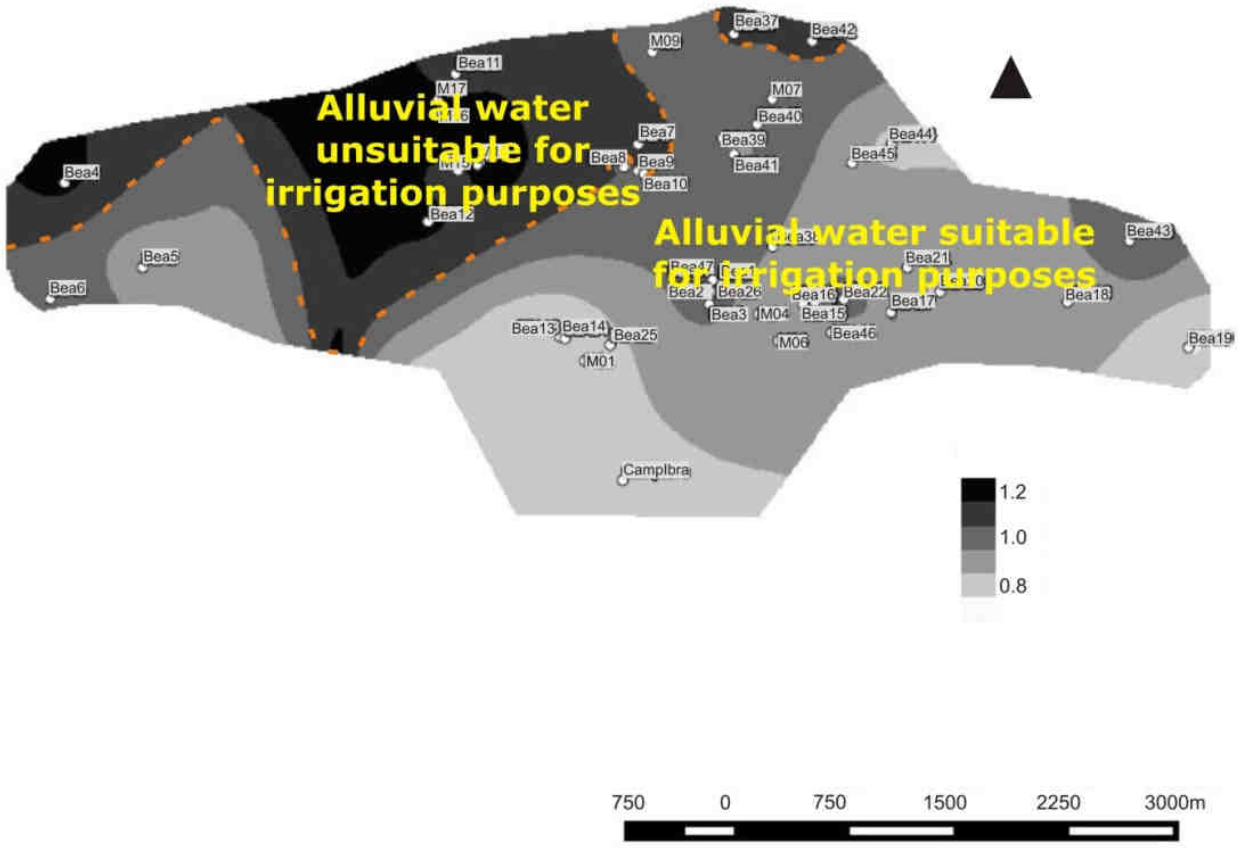

Fig. 4. Kelly's ratio for alluvial waters of the Mhamid Oasis in October 2015 
This situation requires using appropriate agrotechnical techniques. Water for irrigation is also assessed in terms of magnesium content. Magnesium hazard classifies $30 \%$ of alluvial waters of the oasis as unsuitable for irrigation (Fig. 3). The excess of magnesium results in the limitation of plants' intake of necessary substances like calcium and potassium. Kelly's ratio, based on the calcium, magnesium and sodium content, also classifies $30 \%$ of alluvial waters researched as unsuitable for irrigation (Fig. 4). Alluvial waters of the oasis were also assessed with the use of the permeability index (Fig. 5).

Soil permeability is the ability of the ground to permeate water, which may be impeded as a result of salts' accumulation. The permeability index $(P I)$ classifies the researched waters as moderately good for irrigation. The $S A R$, often used in assessment of water for irrigation purposes $[4,8,9]$ amounts from 5 to 16 for waters of Mhamid Oasis. SAR informs about the possible level of ion exchange between sodium and calcium and magnesium. Considering only the $S A R$, the waters belong to the excellent and good for irrigation classes.

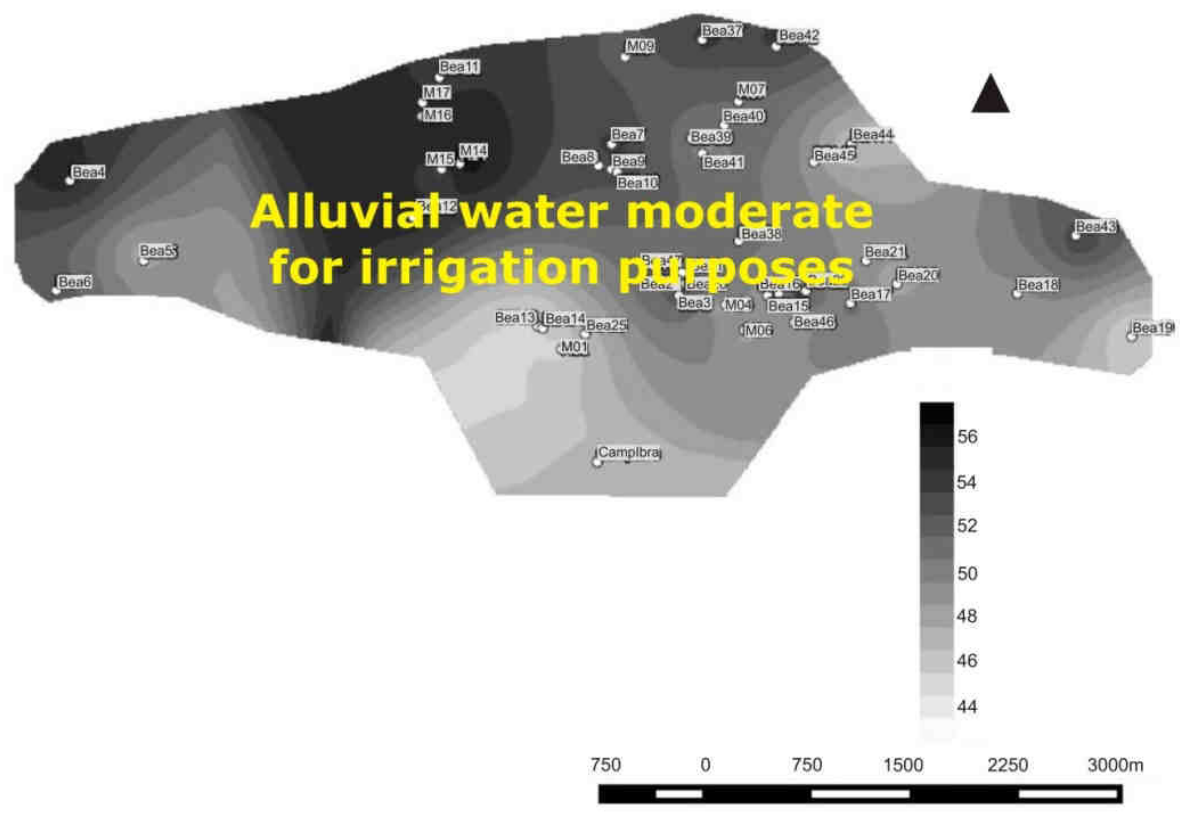

Fig. 5. Permeability index for alluvial water of Mhamid Oasis in October 2015

However, to assess usability of the waters for irrigation purposes, we also had to consider the condensation of sodium and other salts. In these cases, the electric conductivity $(E C)$ was used. Both parameters, $S A R$ as well as $E C$, are classified together on the Wilcox's diagram [5]. Figure 6 shows the classification of tested alluvial waters with the use of Wilcox's diagram. According to the classification the waters belong to the S1 and S2 classes, i.e. of low and medium sodium hazard, whereas in terms of salinity hazard the waters belong to the group $\mathrm{C} 4$, i.e. to the waters of a very high salinity hazard.

In the area of Mhamid Oasis, of a total surface of $40 \mathrm{~km}^{2}$, a diversified usability of alluvial waters for irrigation has been observed. The least favourable waters, according to 
the $S A R / E C,(\% N a), K R$ and $P I$ classifications, for irrigation purposes, occur in western and north-western part of the oasis. It is related to their flow in alluvia from the east to the west, during which they are enriched with dissolvable salts, especially with $\mathrm{Cl}^{-}$and $\mathrm{Na}^{+}$ions. However, the highest salinity in the north-western part of the oasis probably results also from the regulation of the Draa river flow that, during water discharges, directs the most salinated waters to this part of the oasis. Different tendencies are only observed in terms of $\mathrm{MH}$, what indicates that the least favourable waters for irrigation occur in the northern part of the oasis and that they improve as they get further from the main riverbank of the Draa river, and the lowest indicators for the index are for the southern part of the oasis.

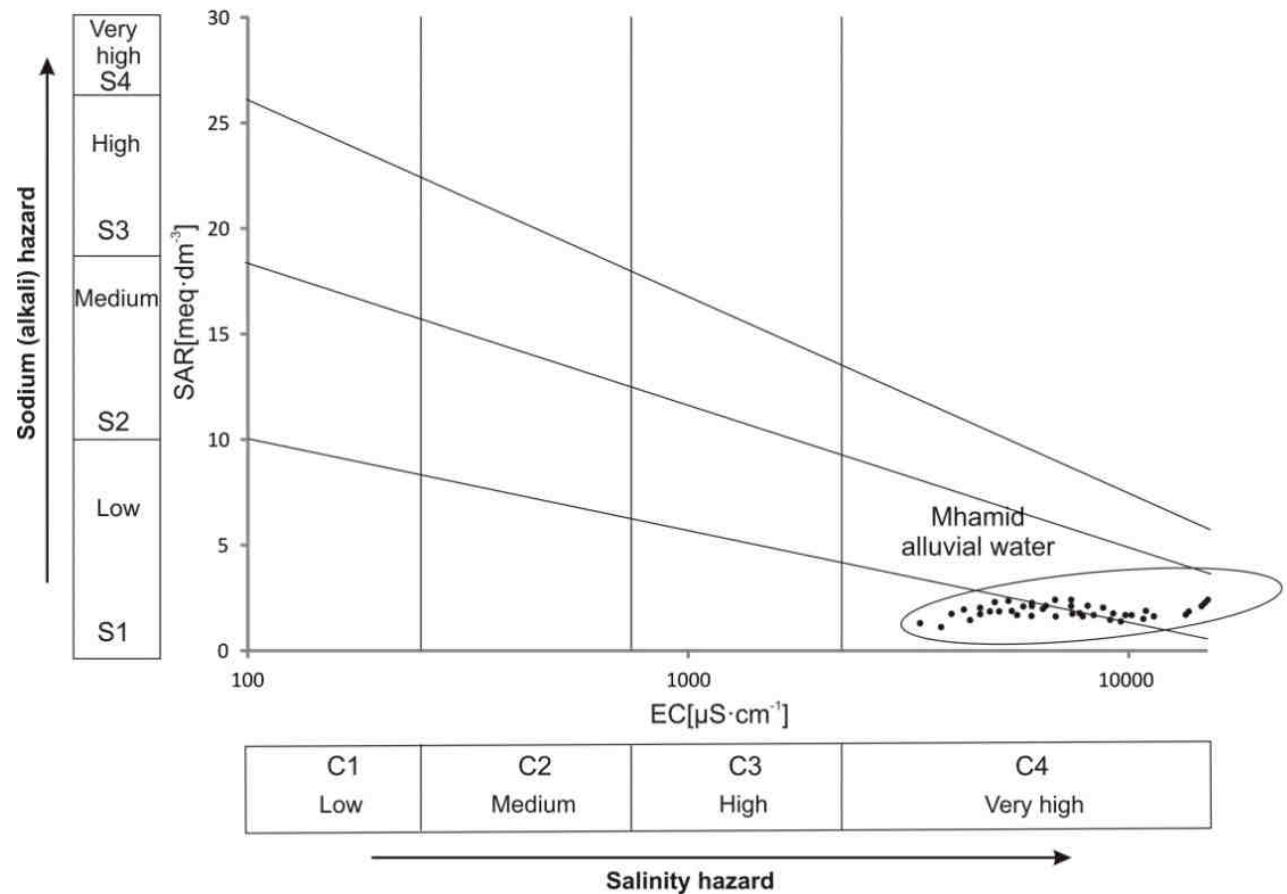

Fig. 6. Chart using $S A R$ and $E C$ together to assess irrigation water

\section{Conclusions}

The Mhamid Oasis, located in the hot arid zone, is an example of the area in which problems with availability of water suitable for irrigation occur frequently. Surface waters directed to the oasis and distributed by open channels are susceptible to a rapid growth of salinity resulting from significant evapotranspiration. Whereas the alluvial waters, which are used for irrigation purposes more and more frequently because of the smaller amount of water discharged to the oasis from the Mansour Ed Dahbi reservoir, show the high content of salt. Magnesium hazard and Kelly's ratio classify approximately $30 \%$ of them as unsuitable for irrigation. The $S A R$ confirms their high susceptibility to salinity. The permeability index $(P I)$ classifies the waters tested as medium, and in terms of sodium content, the waters are appropriate for irrigation purposes. It has been found that even in the 
small area of the oasis, the usability of alluvial waters for irrigation purposes is varied. It is related to their flow in alluvia, in which they are enriched with dissolvable salts.

Considering that alluvial waters are a potential source of water for irrigation in arid zones, the consequences of irrigation with highly salinated waters should be noted. The excess of sodium destroys the soil structure that loses the ability to support plants' growth. Moreover, salination leads to reduction of soil permeability, what can make cultivation impossible.

\section{References}

[1] El Mandour A, El Yaouti CF, Fakir CY, Zarhloule CY, Benavente CJ. Evolution of groundwater salinity in the unconfined aquifer of Bou-Areg, Northeastern Mediterranean coast, Morocco. Environ Geol. 2008;54:491-503. DOI: 10.1007/s00254-007-0842-3.

[2] Kudoda AM, Abdalla OAE. Hydrochemical characterization of the main aquifers in Khartoum, the capital city of Sudan. Environ Earth Sci. 2015;74:4771-4786. DOI: 10.1007/s12665-015-4464-x.

[3] Ammar BS, Taupin JD, Zouari K, Khouatmia M. Identifying recharge and salinization sources of groundwater in the Oussja Ghar el Melah plain (northeast Tunisia) using geochemical tools and environmental isotopes. Environ Earth Sci. 2016;75:606. DOI: 10.1007/s12665-016-5431-x.

[4] Fakharian K, Narany TS. Multidisciplinary approach to evaluate groundwater salinity in Saveh Plain, Iran. Environ Earth Sci. 2016;75:624. DOI: 10.1007/s12665-015-5104-1.

[5] Wilcox LV. Classification and Use of Irrigation Water. USDA; 1955. https://www.ars.usda.gov/arsuserfiles/20360500/pdf_pubs/P0192.pdf.

[6] Deshpande SM, Ather KR. Evaluation of groundwater quality.and its suitability for drinking and agriculture use in parts of Vaijapur, District Aurangabad, MS, India. Res J Chem Sci. 2012;2(1):25-31. http://www.isca.in/rjcs/Archives/v2/i1/04.ISCA-RJCS-2011-216_Done.php.

[7] Alaya BM, Saidi S, Zemni T, Zargouni F. Suitability assessment of deep groundwater for drinking and irrigation use in the Djeffara aquifers (Northern Gabes, south-eastern Tunisia). Environ Earth Sci. 2014;71(8):3387-3421. DOI: 10.1007/s12665-013-2729-9.

[8] Ghazaryan K, Chen Y. Hydrochemical assessment of surface water for irrigation purposes and its influence on soil salinity in Tikanlik oasis, China. Environ Earth Sci. 2016;75:383. DOI: 10.1007/s12665-016-5287-0.

[9] Houatmia F, Azouzi R, Charef A, Bedir M. Assessment of groundwater quality for irrigation and drinking purposes and identification of hydrogeochemical mechanisms evolution in Northeastern, Tunisia. Environ Earth Sci. 2016;75:746. DOI: 10.1007/s12665-016-5441-8.

[10] Wang YG, Li Y, Xiao DN. Catchment scale spatial variability of soil salt content in agricultural oasis, Northwest China. Environ Geol. 2008;56:439-446. DOI: 10.1007/s00254-007-1181-0.b.

[11] Ghassemi F, Jakeman AJ, Nix HA. Salinisation of Land and Water Resources: Human Causes, Extent, Management and Case Studies. Wallingford: CAB International; 1995; 526 p.

[12] Ahmed MA, Abdel Samie SG, Badawy HA. Factors controlling mechanisms of groundwater salinization and hydrogeochemical processes in the Quaternary aquifer of the Eastern Nile Delta, Egypt. Environ Earth Sci. 2013;68:369-394. DOI: 10.1007/s12665-012-1744-6.

[13] El Maghraby MMS. Geochemical and isotopic evidence of seawater intrusion into the shallow pleistocene coastal aquifer, West Alexandria Egypt. Life Sci J. 2014;11(7):749-762. http://www.lifesciencesite.com/lsj/life1107/110_25356life110714_749_762.pdf.

[14] Kijne JW. Water and salinity balances for irrigated agriculture in Pakistan. Research Report 6. Colombo, Sri Lanka: International Irrigation Management Institute (IIMI); 1996. http://www.iwmi.cgiar.org/Publications/IWMI_Research_Reports/PDF/pub006/REPORT06.PDF.

[15] Ma JZ, Wang XS, Edmunds WM. The characteristics of ground-water resources and their changes under the impacts of human activity in the arid Northwest China - a case study of the Shiyang River Basin. J Arid Environ. 2005;61:277-295. DOI: 10.1016/j.jaridenv.2004.07.014.

[16] Bouchaou L, Michelot JL, Vengosh A, Hsissou Y, Qurtobi M, Gaye CB, et al. Application of multiple isotopic and geochemical tracers for investigation of recharge, salinization, and residence time of water in the Souss-Massa aquifer, Southwest of Morocco. J Hydrol. 2008;352:267-287. DOI: 10.1016/j.jhydrol.2008.01.022.

[17] Warner N, Lgourna Z, Bouchaou L, Boutaleb S, Tagma T, Hsaissoune M, et al. Integration of geochemical and isotopic tracers for elucidating water sources and salinization of shallow aquifers in the sub-Saharan Drâa Basin, Morocco. Appl Geochem. 2013;34:140-151. DOI: 10.1016/j.apgeochem.2013.03.005. 
[18] Dłużewski M, Krzemień K. Physical and geographical characteristics of Coude du Dra region. In: Dłużewski M, editor. Modern Evolution of the Natural Environment of the Coude du Dra Region (Morocco) and its Impact on the Human Living Conditions. Warszawa: Academic Publisher Dialog; 2003:11-44.

[19] Sobczak K. Changes in the environment and migration in the south Morocco - the example of Mhamid oasis. Miscellanea Geographica Warszawa: Uniwersytet Warszawski; 2008;13:239-250.

[20] Richards LA. Diagnosis and Improvement of Saline and Alkali Soils. Handbook 60. Washington DC: US Dept. of Agriculture; 1954;160 pp.

[21] Ragunath HM. Groundwater, 2nd Ed. New Delhi: Wiley Eastern Ltd; 1987. https://www.ars.usda.gov/ARSUserFiles/20360500/hb60_pdf/hb60complete.pdf.

[22] Kelly WP. Use of saline irrigation water. Soil Sci. 1963; 95(4):355-391. http://journals.lww.com/soilsci/Citation/1963/06000/USE_OF_SALINE_IRRIGATION_WATER_.3.aspx.

[23] Flowers TJ. Improving crop salt tolerance. J Exp Bot. 2004;55(396):307-319. DOI: 10.1093/jxb/erh003.

[24] Mer RK, Prajith PK, Pandya DH, Pandey A. Effect of salts on germination of seeds and growth of young plants of Hordeum vulgare, Tricticum aestivum, Cicer arietinum and Brassica juncea. J Agron Crop Sci. 2000;185:209-217. DOI: 10.1046/j.1439-037x.2000.00423.x.

[25] Martinez V, Creda A. Nitrate reductase activity in tomato and cucumber leaves as influence by $\mathrm{NaCl}$ and $\mathrm{N}$ source. J Plant Nutr. 1989;12:1335-1350. DOI: 10.1080/01904168909364040.

[26] Zhu JK. Plant salt tolerance. Trends Plant Sci. 2001;6(2):66-71. DOI: 10.1016/S1360-1385(00)01838-0.

[27] Jungklang J, Usui K, Masumoto H. Differences in physiological responses to $\mathrm{NaCl}$ between salt-tolerant Sesbania rostrata Brem. \& Oberm. and non-tolerant Phaseolus vulgaris L. Weed Biology Manage. 2003;(3):21-27. DOI: 10.1046/j.1445-6664.2003.00077.x.

[28] Ashraf M. Some important physiological selection criteria for salt tolerance in plants. Flora - Morphol Distribut Functional Ecology Plants. 2004;199(5):361-376. DOI: 10.1078/0367-2530-00165.

[29] Parida AK, Das AB. Salt tolerance and salinity effects on plants: a review. Ecotoxicol Environ Saf. 2005;60(3):324-49. DOI: 10.1016/j.ecoenv.2004.06.010.

[30] Wu J, Qian H, Fang Y. Assessment of soil salinization based on a low-cost method and its influencing factors in a semiarid agricultural area, northwest China. Environ Earth Sci. 2014;71:3465-3475. DOI: 10.1007/s12665-013-2736-X.

[31] Omar SA, Abdel Sater MH, Khallil AM, Abd Alla MH. Growth and enzyme activity of fungi and bacteria in soil salinized with sodium chloride. Folia Microbiol. 1994;39:23-28. DOI: 10.1007/BF02814524. 